\title{
THE RISE AND FALL OF THE GOVERNMENT OF NATIONAL UNITY IN ZANZIBAR A Critical Analysis of the 2015 elections
}

\section{Nicodemus Minde, Sterling Roop and Kjetil Tronvoll}

\author{
Nicodemus Minde is a PhD candidate in the United States International \\ University - Africa, \\ Nairobi, Kenya
}

Sterling Roop is a political analyst in Telluride, Co., USA

Kjetil Tronvoll is Director, Oslo Analytica and Professor and Research Director, Peace and Conflict studies at Bjorknes University College, Oslo, Norway

\begin{abstract}
This article analyses the pitfalls that characterised the emergence and eventual demise of the Government of National Unity (GNU) in Tanzania's semi-autonomous region of Zanzibar. Drawn from continuous political and electoral observations in Zanzibar, the article analyses how the 2015 general elections contributed to the eventual dissolution of the GNU. The GNU in Zanzibar was a negotiated political settlement between two parties - the incumbent Chama cha Mapinduzi (CCM) and the Civic United Front (CUF). In particular, this article looks at how the start of the constitutional review process in Tanzania contributed to the withering of the GNU. Despite its undeniably noble agenda, the constitutional review process resuscitated old enmities between CCM and the CUF. The two parties' divergent stances on the structure of the Union revived the rifts that characterised their relationship before the GNU. We analyse the election cycle rhetoric following the run-up to the elections and how this widened the GNU fissures leading to its eventual demise after the re-election in March 2016. After the 2015 elections were nullified, the CUF, which had claimed victory, boycotted the re-election. As a result, the CCM won an overwhelming electoral victory.
\end{abstract}

Keywords: Zanzibar, Tanzania, Government of National Unity, elections, reconciliation, political settlement 


\section{INTRODUCTION}

The October 2015 general elections in Zanzibar, a semi-autonomous state of the United Republic of Tanzania, proved to be a watershed. It was the first election after the constitutionalisation and formation of the Government of National Unity (GNU) as the result of the Maridhiano Agreement, the reconciliation agreement entered into prior to the last election in 2010 (Bakari \& Makulilo 2012; Moss \& Tronvoll 2014). The previous general election in 2010 saw the perennial incumbent party Chama cha Mapinduzi (CCM) controversially win by a narrow margin over the opposition party Civic United Front (CUF). Pursuant to the power-sharing agreement, it established itself as the senior and dominating partner in the GNU (Roop, Tronvoll \& Minde 2018). The 2015 election would hence be a litmus test of the robustness and durability of the reconciliation agreement and the consolidation of political stability on the islands under a GNU framework. The GNU in Zanzibar was a power-sharing agreement aimed at managing Zanzibar's electoral and political crisis, a crisis that had lasted for more than a decade following the trend of power-sharing formulas for the management and mitigation of conflicts and political crises (Cheeseman 2011; Mehler 2009).

After two days' delay in the official tabulation and announcement of the final 2015 election results, the CUF called a press conference. In order to pre-empt any manipulation of the numbers as allegedly experienced in previous elections, they presented their unofficial tabulation of the results. These showed a clear defeat of CCM for the first time since the reintroduction of multipartyism in 1992. Immediately thereafter the chairman of the Zanzibar Election Commission (ZEC) unilaterally annulled the election, claiming widespread voting irregularities. After a failed process of interparty talks to negotiate the October 2015 election results, the ZEC called for a re-run election in March 2016. CUF, insisting on the legitimacy of the October 2015 vote, rejected this re-run and decided to boycott the elections. Since Zanzibar is a de facto two-party system, the re-run election resulted in a total victory for CCM, winning the presidency and all the seats in the legislature. By implication, these results meant that the GNU was effectively dead after just one five-year term.

This article explores the political dynamics in Zanzibar and Tanzania from the establishment of the GNU in 2010. It further analyses how they impacted, undermined and eventually led to the discontinuation of the unity government and the Maridhiano political reconciliation framework. The impacts and outcomes of power-sharing agreements have for some time been a subject of analysis in the African context. The viability of unity governments has been analysed according to their institutional transformation and impact on peace and stability, as well as electoral and democratic reforms (see for example Cheeseman \& Tendi 2010; Mehler 2009; Mukherjee 2006). This article is guided by the following questions: 
- How did the constitutional review process of 2011-2013 shape political party positions in Zanzibar

- What influenced the shifting of party loyalties going into the elections in 2015; and

- Did the power-sharing formula in the GNU envisage a sustainable political transition.

This article attempts to answer these questions through an analysis of the electoral cycle of 2015. Given the intense party rivalry in Zanzibar, the paper argues that, unlike the 2010 election cycle which was conducted in a reconciliatory atmosphere, the 2015 election reincarnated old animosities between the CCM and CUF.

The analysis is drawn from a prolonged project on electoral observation and political reconciliation in Zanzibar between 2009 and 2015 in which the authors participated. Through a qualitative research design, the article draws data from observing the constitutional review process, voter registration, campaign rallies and election day. The research also used semi-structured interview data collected from various groups such as journalists, political party representatives, the Constitutional Review Commission, government, the Electoral Commission and ordinary citizens on the island of Zanzibar.

\section{ZANZIBAR'S POLITICAL CONTEXT}

Zanzibar is an archipelago off the East African coast in the Indian Ocean, consisting of the two main islands of Unguja and Pemba. It is a semi-autonomous region under the United Republic of Tanzania. Zanzibar has had a long and turbulent political history from its pre-colonial days to the racialised politics of the colonial and post-colonial era (Killian 2008). Zanzibar was the bastion of commercial activity along the East African coast and is noted in particular for its role in the regional slave trade. As a trading hub Zanzibar cultivated close ties with Oman, the Persian Gulf, India, Kenya and Comoros (Boswell 2008) and thus became an important site for the emergence of mixed cultures and identities.

Intermittent control by the Sultanate of Oman for close to 200 years and thereafter as a British protectorate meant that Zanzibar experienced external dominance for many years. On 10 December 1963, the Zanzibar protectorate was granted independence from Great Britain but it remained under the Sultan, who was violently deposed in a revolution in January 1964. The 1964 revolution replaced a largely Arab government with an African government in which the Afro-Shirazi Party was the dominant actor. On April 26 1964, Zanzibar joined with Tanganyika to form the United Republic of Tanzania. To consolidate the Union, in 1977 the ASP merged with the Tanganyika African National Union 
(TANU) to form Chama Cha Mapinduzi (CCM) - the Revolutionary Party. CCM has since dominated politics in Tanzania and Zanzibar.

\section{THE MARIDHIANO AGREEMENT AND THE CONSTITUTIONALISATION OF THE GNU}

Zanzibar elections have been fraught with violence and accusations of rigging and manipulation since the return to multiparty politics in 1995. After every election there have been attempts to negotiate and reach a political settlement between CCM and CUF on the consolidation of peace and democracy on the isles (see for example Anglin 2000; Cameron 2002; Karume 2006). The Muafaka accords, as they were labelled (Muafaka means reconciliation in Swahili), largely failed to be implemented due to a lack of trust between the parties and the incumbent's hesitation to relinquish power (Karume 2006).

New outbursts of violence occurred with the commencement of the voter registration process in August 2009 during the run-up to the 2010 elections. Concern about sustained violence and economic decline on the islands led the two senior political leaders, the incumbent President Amani Abeid Karume who was reaching the end of his second term in office, and the CUF leader Maalim Seif Sherif Hamad, to initiate confidential talks. A secret inter-party committee was established consisting of three trusted representatives from each side, led by the most senior CCM revolutionary Mzee Hassan Nassor Moyo. ${ }^{1}$ The Moyo Committee, as it was called, advised President Karume and Maalim Seif on a reconciliation framework based on the establishment of a GNU. Previous attempts at brokering the political impasse in Zanzibar (Muafaka I and Muafaka II) had paid few dividends in terms of a political settlement. The Moyo Committee proposal led to the historic event on 5 November 2009 when President Amani Abeid Karume and CUF's leader Seif Shariff Hamad met at State House in Stone Town. They committed themselves by a hand-shake agreement - a gentleman's agreement - to an amicable settlement of the long and protracted political crisis which had haunted the islands for decades (Bakari \& Makulilo 2012).

The resultant agreement, called the Maridhiano (reconciliation accord) signaled a commitment to reconciliation and pacification between CCM and CUF parties through the establishment of a unity government. It included grassroots participation on the two islands of Unguja and Pemba. In order to institutionalise and formalise the accord, CUF presented a private motion in the House of Representatives proposing constitutional amendments to the 1984 Zanzibar

1 The three members from CCM were Hassan Nassor Moyo (Chairman), Mansour Yusuf Himid and Mohamed Al Mugheiry Riyami while CUF members included Abubakar Khamis Bakari, Ismail Jussa Ladhu and Salim Bimani. 
Constitution to cater for the formation of a GNU, creating two vice president positions and a sharing of cabinet posts. In addition, as a show of common interests and nationalism, the amendments furthermore declared Zanzibar to be one of the two constituent countries under the United Republic of Tanzania. In a subsequent referendum held on 31 July 2010, some $66.4 \%$ of voters approved the formation of a GNU, to be effected depending on the outcome of the October 2010 general elections (Nassor \& Jose 2014).

Unlike the previous elections of 1995, 2000 and 2005, the 2010 elections were largely peaceful from the start of the campaigns to the announcement of the election results. The spirit of Maridhiano was evident in the electioneering process, with the political environment remaining largely positive and calm. This was made possible by the reconciliatory campaign messaging from President Amani Karume (CCM) and opposition CUF leader Seif Shariff Hamad on the need to unite all Zanzibaris. The leadership was focused on initiating and implementing change by fostering leadership trust between the two parties and bridging the identity gap between the parties and the people of Zanzibar (Moss \& Tronvoll 2014). The 2010 results were similarly controversial, but with heavy pressure from the mainland on CUF presidential candidate Maalim Seif, and in the spirit of Maridhiano the two leaders accepted CCM's candidate Ali Mohammed Shein. They agreed to declare him as the winner of the 2010 general elections with $50.1 \%$ of the vote, with CUF's Seif Shariff Hamad garnering $49.1 \%$ of the vote. In other words, this was a manifestation of a true Maridhiano result. Building on the work of Andreas Mehler (2009) together with that of Aley Soud Nassor and Jim Jose (2014), we argue here that whereas power-sharing agreements can resolve political crises through position sharing, intervening factors such as the constitutional review process and the 2015 election process contributed to the fall of the GNU in Zanzibar.

\section{THE FORMATION OF THE GNU}

The GNU was established in November 2010 with Ali Mohammed Shein as President, Seif Shariff Hamad as the largely ceremonial first vice-president and Seif Ali Iddi as the second vice-president and leader of government affairs in the House of Representatives. The president subsequently appointed a cabinet comprising 16 line ministers and 3 ministers without portfolio, with a fair amount of balance between the two partners in terms of the key ministries, though CCM retained the most powerful and important ministries.

In its inception, the GNU had broad-based popular support and was carried forward by a societal euphoria celebrating the fact that the political conflict that had ridden the islands for decades was finally settled. Top-level leaders and 
ministers from both parties expressed surprise that the working spirit in the cabinet was very amicable and constructive in its first year or so. Gradually, however, the GNU was overtaken and impacted by a set of political events. Eventually these would derail the Maridhiano process and lead to the collapse of the GNU after its first period in existence.

\section{CONSTITUTIONAL REVIEW PROCESS AND THE GNU}

The main issue to undermine the collaborative spirit in the GNU was the Tanzanian constitutional review process which commenced in late 2011. As anticipated, the Union issue, that is the organising principles of the relationship between the autonomous political entity of Zanzibar and the Union level (reflecting the mainland) dominated the review process. There were two crucial Union issues on which CCM and CUF diverged:

(a) Which issues should be included under 'Union matters', and which should be left to the prerogative of Zanzibar to decide upon alone;

(b) What government structure should Tanzania adopt:

- continue the status quo of a two-government asymmetrical union structure (a Zanzibar executive, government, and legislature deciding on all non-Union matters prevailing to Zanzibar; and a combined Union executive, government and legislature deciding on all Union matters for both entities, in addition to serving as an executive, government and legislature for mainland affairs);

- or transform into a three-government structure (which had a rather lean Union government overseeing Union matters for both entities and a separate executive, government and legislature for Tanganyika mainland and Zanzibar respectively).

These positions were founded on long-held popular grievances among large segments of Zanzibar's population to the effect that the Union framework discriminated against and marginalised Zanzibar's interests and rightful prerogatives under the original Articles of the Union, as was intended in 1964 (Tronvoll 2006).

The review process was initiated by Union president Jakaya Kikwete in late 2011 and was aimed at collecting citizens' opinions on a new constitution. CCM was torn between one faction advocating for reform, and another that was happy with the status quo. According to one Constitutional Review commissioner, 'CCM's opinion was flexible. Of course, they proposed a two-government 
structure, because that is their party policy, but they are ready for change.' (Anonymous interview in Zanzibar, June 2012). CCM had accepted that many of the Union issues could be removed, including international cooperation, which would facilitate the long sought-after direct bilateral development programs for Zanzibar. Prominent CCM members in both Zanzibar and the mainland admitted that change was coming and it was likely that three governments would be the format agreed upon for the Union in the new constitution. CCM was apparently more concerned about reforming the local government systems, a move which a majority of citizens, political parties and NGOs all supported. Such a reform would negatively impact CCM as it would challenge their hold on power in local and regional governments in the short term and their grip on the central government in the longer term. The reason for this was the decentralisation of power through the scrapping of regional commissioners (RCs) and district commissioners (DCs) and replacing them with elected officials.

In Zanzibar, discussions with CCM officials recognised that CUF was scoring political points by capitalising on the advent of Zanzibari nationalism in the wake of the formation of the GNU and the Union debate. They also acknowledged that the likely outcome of the process would be a three-government structure. As one more progressive CCM member put it, 'it is good CUF wants the Treaty-based Union because then we can support three governments in the Constitutional Assembly and referendum without appearing to give in to the opposition, which is still unthinkable here' (Interview, Zanzibar May 2014). This statement must be seen against a backdrop where just a few years earlier people could be arrested if they advocated for Union reform.

CUF as a party was divided over the constitutional process, and the split generally ran along the mainland vs. Zanzibar sides of the party. The party's official stand was and continues to be a three-government structure Union; however, in his submission to the CRC, Secretary-General Maalim Seif Shariff Hamad argued in favour of a treaty-based Union. This concept involved a splitsovereignty model (where both Zanzibar and Tanganyika were sovereign entities), with the European Union and the East African Community as reference points.

On the other hand, CUF National Chairman Ibrahim Lipumba, from mainland Tanzania, warned that the political Union had existed for nearly 50 years. A break would not be clean and his colleagues in Zanzibar were not taking into account the potential hazards of advocating such a policy (interview, Dodoma, July 2014). Lipumba further explained that since the Union of Tanzania is primarily a political one, to argue for an economic model based on the EU or EAC is wrong and dangerous, given the religious tensions and political immaturity of Tanzanian society. According to him the two parties to the Union were currently 
too intertwined to break up and the cost to ordinary citizens would be too high. In Zanzibar however, the party and its leaders remained fully committed to pushing a strong nationalistic agenda towards sovereignty, and repeatedly stated that they would not back down from this position. CUF's position was enhanced further by an Islamic NGO called UAMSHO (Swahili for Awakening) which advocated for a break-up of the Union and full Zanzibari sovereignty. With the GNU taking shape, the constitution review process began affecting the discourse within both parties as well as unity in the cabinet.

\section{QUALMS ABOUT THE CCM}

The low turnout in CCM strongholds in Zanzibar and the referendum for establishing a GNU in 2009 indicated that large segments of the CCM leadership and constituency were obviously hesitant about accepting the arrangement. President Karume had more or less single-handedly imposed the Maridhiano solution on the party and chastised anyone opposing it. After President Karume stepped down, his faction and followers within CCM were under pressure from the new hardline leadership. The three CCM members of the Maridhiano committee were the first to feel the consequences.

Because of the political opinions articulated during the constitutional review process, these three influential CCM party cadres were either expelled from the party or defected. In an unprecedented manner all three subsequently shifted their allegiance to CUF and began supporting Maalim Seif in the run-up to the 2015 elections. Key among them was Mzee Hassan Nassor Moyo, a CCM longserving stalwart and one of the original members of the Revolutionary Council after the Zanzibar Revolution in 1964. He was a founding member of the Afro Shirazi Party in Zanzibar and helped to oversee the merger of TANU and ASP to create CCM in 1977. Mzee Moyo was a crucial pillar in the reconciliation talks that pacified CCM and CUF and led to the formation of the GNU in 2010. CCM accused Mzee Moyo of betraying the party through his three-government Union stance, and in April 2015 CCM announced that it had expelled him from the party (Sadallah 2015). Mzee Moyo's expulsion came a year after yet another member of the reconciliation team, Mansour Yussuf Himid, was dismissed from the party in August 2013 over similar accusations.

The expulsion of Mzee Moyo was significant for a number of reasons. First, CCM party officials in Zanzibar had become increasingly antagonised by Moyo's stance supporting a sovereign Zanzibar. In particular, his public announcements supporting the CUF stand on the Union at political rallies, where he appeared to be working directly against CCM interests and positions, had aroused their ire. For example, according to researchers at a rally in Chaani, Zanzibar on 
28 December, Mzee Moyo publicly castigated some CCM members for not supporting the reconciliation agenda. Moyo's support for the treaty based on the three-government structure and with full sovereignty for Zanzibar posed a real threat to CCM in Zanzibar. It directly undermined their support of the proposed constitution which endorsed the status quo. CUF was trying to capitalise on the growth of Zanzibar nationalism not only to oppose the proposed constitution, but also to win State House in Zanzibar in 2015. Therefore, even though Moyo had not openly advocated for CUF, he knowingly opposed his party's position and in effect strengthened the opposition. Second, his detailed knowledge of the inner workings of CCM and support of more moderate factions in CCM Zanzibar were considered an asset in increasing support for CUF. Moyo's expulsion also strengthened CUF's attempts to recast and remodel themselves as the party defending and fighting for the ideological underpinnings of the Zanzibar Revolution, thereby appropriating CCM's main political argument and legacy.

Third, as the chairman of the informal bipartisan Maridhiano committee, Moyo appeared to give CUF full ownership of the GNU format and Maridhiano concept. The election was shaped by this turn of events with CCM distancing itself from the Maridhiano committee as well as the GNU format, as CUF increasingly embraced both in their manifesto and on the campaign trail. ${ }^{2}$ CUF would most probably capitalise on this by branding itself as the party for peace, stability and continued political reconciliation. ${ }^{3}$

Mzee Moyo was critical of CCM Zanzibar's handling of the Union issues debate as well as CCM's commitment to reconciliation (Sadallah 2015). Mansour Yusuf Himid, another senior CCM cadre and minister, was also frustrated by his party and was later expelled, in the process losing his constituency seat of Kiembe Samaki. Later he defiantly joined CUF. As with Mzee Moyo, Mansour differed from his party on the format and structure of the Union. In particular, Mansour admitted that CCM had played the racial card in previous elections that divided the people of Zanzibar. Mohamed Al Mugheiry Riyami, the third member of the Maridhiano Committee and a trusted CCM cadre, had announced his defection from the party in August 2013. Like the others Riyami said he was disillusioned by the CCM's stance on the Union, accusing them of selling off the country and party in Tanzania's capital Dodoma. In addition, there were several

2 The CUF Election manifesto constantly reiterated claims of what a CUF-led GNU would do. This was in stark contrast to CCM. Both manifestos can be found here: http:/ / www.temco.udsm.ac.tz/ images/stories/Election_Manifesto/ILANI_CCM_2015.pdf and http:/ / www.temco.udsm.ac.tz/ images/stories/Election_Manifesto/ILANI_CUF_2015.pdf

3 This was exemplified in CUF's muted responses to alleged attacks on CCM's premises and supporters in Dimani in April 2015. 
defections by other cadres and party officials, leaving the CCM party exposed ahead of the 2015 elections. ${ }^{4}$

\section{SHIFTING LOYALTIES IN ZANZIBAR}

Political competition in Zanzibar has been shaped largely by the politics of identity waged by the political leadership on the basis of race. Communal identities are, however, neither wholly inherited nor wholly invented, but are an overlap of the two (see for example Glassman 2011; Killian 2008). These identities have influenced and shaped all aspects of social, economic and political lifestyles in Zanzibar. Regarding the political aspect, these identities have historically shaped voting patterns and behavior in Zanzibar.

During the pre-election period we observed a shift in political behaviour in Unguja, an island historically dominated by CCM. These shifts were observed across the island but were particularly noteworthy in the old CCM strongholds of central, north and southern Unguja. In southern Unguja strong support has been shaped by a combination of revolutionary legacy and extreme levels of deprivation, causing a patrimonial symbiosis between the people and the government. In April 2015 the CUF, which had been banned from the area, held a large rally in the southern regional capital of Makunduchi at the invitation of the local community. At the rally an estimated 500 youths showed up and defected from CCM to CUF, according to local journalist interviewed on 9 June 2015 in Stone Town, Zanzibar. In an interview the previous day a senior government official, who spoke on condition of anonymity, shared these sentiments: 'The shifts are glaring and it is remarkable in the public service. This is partly as a result of the failure in the constitution process and the rise of Zanzibar nationalism.'

It was evident in our fieldwork observation that CUF's advocacy for full sovereignty was a key factor in the shifting loyalties among the youth and middle class in Zanzibar. One youngster who defected from CCM to CUF expressed his feelings in an interview on 10 June 2015 in Makunduchi: 'We want to reclaim our dignity, we want our country back, and we want a free port and more jobs'.

\section{CO-OPTING THE REVOLUTIONARY LEGACY}

Politics in Zanzibar has been dominated by hostile images born out of geographical locations, political allegiances, descent, ethnicity and even race (Moss

4 As for instance Juma Hamad Omar, a former CCM Minister in Salmin Amour's government, who defected to CUF and ran on a CUF MP ticket in Wawi constituency (Pemba) in the 2015 election; and Mohammed Hashim, a former deputy minister and commissioner of the Zanzibar Revenue Board (ZRB) who ran on a CUF ticket in Dimani constituency. 
\& Tronvoll 2014). The 1964 Zanzibar Revolution has been an important historical legacy in state formation in Zanzibar, one that imbues a sense of identity and independence to the people. For CCM the revolution symbolises its raison d'être and the party has always seen itself as the custodians of the 1964 revolution. CCM literarily means 'the party of the revolution' and it has built its legitimacy on that legacy, as reflected in their key party slogan 'Mapinduzi Daima', Swahili for 'Revolution Forever'.

CCM views the revolution as an economic, social, and political reform that wrested power from the Arab oligarchy and their British colonial supporters in Zanzibar (Mmuya 2003). CUF has in the past challenged the 1964 revolution and has lambasted the decay of the revolutionary ideals (Fouéré 2014). The Afro-Shirazi Party (ASP), the precursor to CCM, advocated for African nationalism and imbued aspects of racialism, which led to the overthrow of the Arab oligarchy in 1964. When CCM was formed in 1977 after the merger between ASP and Tanganyika's TANU, ASP remained a symbolic relic.

In the period leading up to the election CUF consciously designed a strategy to co-opt the revolutionary legacy, partly because of the recent defections of key CCM senior cadres and also due to the rise of Zanzibar nationalism. The revolutionary discourse was co-opted in many CUF pre-election rallies and throughout the campaign. The flags of the revolutionary party ASP were flown in CUF rallies and the 'Mapinduzi Daima' mantra was used, much to the delight of CUF followers. For most CUF supporters the use of this chant during the campaigns was seen as a triumph over CCM and a preparation to take power. To them CCM had betrayed the revolutionary legacy through their antipathy to the reconciliation agenda as well as the derailing of the constitutional review process. They rallied on Zanzibari nationalism through the 'Zanzibar Kwanza - Zanzibar First' motto in reference to the contested relationship in the Union, that is the conflictual interpretations and different perceptions of the Union as seen from mainland and Zanzibar. The 'Zanzibar First' motto was popularised in CUF rallies throughout Zanzibar in the period leading to the 2015 elections.

Mansour Yusuf Himid, ex-CCM minister, took up the role of CUF campaign coordinator. Running on a CUF ticket as the candidate for the Zanzibar House of Representatives, he championed the revolution by honouring the heroes of the revolution, explaining the true meaning of revolution. Speaking during a public rally in Zanzibar in December 2013, he explained that the revolution envisioned an equal society, one that respects the rights of all regardless of race, religion or color. The rhetoric was particularly effectual, since it was delivered by Mansour, the son of one of Zanzibar's revolutionary leaders who was married to the granddaughter of Zanzibar's first president, Abeid Amani Karume. In a CUF rally on 21 February 2015, Mansour told the crowd that this was the start of '... a 
journey to a government of the people, to carry forward the hopes of the people and to result from and serve the people...' (Hamid 2015, author translation). The rally used revolutionary symbolism, including the CCM chant of 'Mapinduzi Daima', posters showing CUF presidential candidate Maalim Seif with Zanzibar founding president Abeid Amani Karume, as well as flying the original Zanzibar flag used after the revolution and before the creation of the United Republic.

This symbolism fitted into the broader CUF narrative that they were the party seeking to fulfil its re-emergence and reclaim its past glory. Building on Mansour's speech, Maalim Seif spoke about how CUF and its leaders would not only lead Zanzibar to full sovereignty, but also build a new economy turning Zanzibar into the Dubai or Singapore of East Africa. ${ }^{5}$

These emerging trends were also seen in the rise of the UAMSHO movement, the Islamic mobilisation NGO, which spoke of the imbalances of the Union and promoted secession and Zanzibari nationalism. The movement gained prominence at the height of the constitution-making process and spoke of 'reclaiming Zanzibari independence' (Fouéré 2014). The message from UAMSHO resonated with that of CUF and by virtue of this CCM was quick to associate the two. In 2012, leaders of the movement were arrested for engaging in violent social protest during their agitation for Zanzibari independence (Hutton 2015). The UAMSHO leaders were jailed in mainland Tanzania, and CUF, in its campaign rhetoric, promised to release them should they win the elections.

In order to retaliate against the CUF's adoption of revolutionary rhetoric, CCM reintroduced the return of the Sultan narrative that had been used effectively to stigmatise the party in previous campaigns in the 1990s and early 2000s. During a public rally in northern Zanzibar, CCM reiterated that CUF's intention, once elected into office, was to bring back the Sultan through the back door (State House, 2015). The racial card was used explicitly and deliberately at several CCM rallies. For instance, Second Vice President Seif Ali Iddi tried to label CUF as a racially discriminating party at a campaign rally in northern Zanzibar 27 September 2015: 'Maybe because I am black and I can't pretend to be white like Jussa (a senior CUF cadre of Indian descent). If am black, that is how I was created by God. I assure you CUF will fall [lose the election].'

During the months leading up to the elections political rhetoric became increasingly divisive. CUF leadership made provocative statements about CCM not giving away power and that CUF would feel obliged to defend a CUF victory and 'take over control'. On the other hand, CCM stated that they would never hand over power [to CUF] by the ballot box since they had taken power by force during the Revolution.

5 CUF issued its manifesto for Zanzibar 21 September 2015. This manifesto presented a vision of a Zanzibar with full self-governing authority - A new Zanzibar: Full Sovereignty, Prosperity for all within a Union with Tanganyika. It outlined its position for a three-government format. 


\section{A SHAKY GNU DURING THE CAMPAIGNS}

Maridhiano had withered, the political divide in Zanzibar had widened even before the start of the official campaign, and the fissures were evident. Some bold CCM members spoke out publicly against the GNU and argued that CCM should not co-operate with the adversarial CUF in government. The CUF, on the other hand, blamed CCM for conspiring to derail the GNU in order to revert to a position of political instability, which arguably gave CCM an excuse to use agents of law enforcement to restrict and intimidate the opposition. It is widely believed that the existence of the GNU had, to a great extent, restrained hardliners in CCM from taking advantage of the state and its coercive power.

CCM's pre-GNU political advantage was the monopoly of state power, which included decision-making in government without the knowledge of the opposition. Under GNU, the CUF gained considerable insight into the inner workings of government and government operations, giving them a great psychological advantage in the campaigns and elections. Furthermore, First Vice President Maalim Seif was for the first time conducting the political activities of his party under the protection of the state's security forces, unlike the past where he could easily have been restrained by the same security forces which were now legally obliged to protect him. Most of these advantages exploited by the ruling party during electoral races prior to the establishment of the GNU were now limited, adding to the sense of urgency and tension in the 2015 electoral cycle, with a level playing field in the run-up to the election.

Tensions between CCM and CUF escalated during the final days before the dissolution of the House of Representatives ahead of the elections in October 2015. For example, CUF members, including ministers in the government, boycotted the end of budget session because of allegations of irregularities and manipulation in the voter registration process by CCM. In retaliation, CCM house members voted to block First Vice President Maalim Seif from attending the presidential speech officially dissolving the House of Representatives before the elections. The GNU government appeared to be a government in name only, as the two parties' relationship was characterised more by confrontation than co-operation in the run-up to the elections. In an interview on 30 July 2015 journalist Ally Saleh, the CUF MP for Malindi constituency in Zanzibar, stated that 'The GNU is facing a rough patch, there is no trust anymore. The strained relations between CUF and CCM are bad sign for Zanzibar as we approach the elections'.

\section{RE-EMERGING ENEMY IMAGES IN THE ELECTION CAMPAIGN}

The election campaigns in Zanzibar officially began on 7 September 2015 with campaign discourse characterised by increasingly divisive rhetoric. CUF and its 
presidential candidate Maalim Seif campaigned fiercely and reiterated that they would not allow their victory to be stolen as had allegedly been done in the past. At a rally in Nungwi on 18 October 2015 observed by researchers, Maalim Seif said 'This time I will not stop anyone from demanding his right. The youth are here and they are ready. I will be the president Inshallah! [God willing]'.

The main campaign promise from CUF, as outlined in their party manifesto, was increased autonomy for Zanzibar through a re-negotiation of Zanzibar's position within the Union. CUF subtly promised the full autonomy they believed would strengthen the Union in the long run, by emphasising principles of justice, equality and respect between the two states in the Union. In this regard, they outlined direct Zanzibari international relations and co-operation (bypassing the Union) as a key promise. In particular, the party emphasised Zanzibar's right to own the oil and gas within Zanzibari territories, which is a concern of Union and under the authority of the Union government. It is important to observe that during the constitutional review process, the Zanzibar and Union governments agreed in principle that oil and gas would not be a Union issue and Zanzibar would have autonomy over the resource. The CUF promised to develop and pass an oil and gas law and a policy for sustainable development within 100 days of taking office. The CUF leadership had always projected the party as one that would stand by the ideals of Maridhiano, and pursuant to their manifesto they promised to protect, maintain and build a cohesive society in the Maridhiano spirit.

CCM campaigned in general on a development platform, as outlined in their party manifesto. CCM Zanzibar's manifesto falls under the CCM Union Manifesto and focused on strengthening the current Union format by seeking alternative measures to solve the Union challenges under a continuation of a two-government system (see CCM Manifesto 2015-2020). The CCM party also promised victory to their supporters. At a rally in October 2015 addressed by CCM Union presidential candidate John Magufuli, CCM supporters sang victory songs saying that CCM would never allow CUF to take office. The tone on the ground was confrontational, undermining the Maridhiano spirit enshrined through the GNU. This sentiment emanated from the revolutionary legacy and CCM's long-standing perception of themselves as the patrons of the revolution, safeguarding and protecting its fruits. Translated into operational politics, this came to mean that only another revolution would unseat the party from power in Zanzibar. This was explicitly articulated in a controversial statement made by CCM's Asha Bakari during the constitution review process in the Constituent Assembly (CA) debates in Dodoma: 'Zanzibar is a revolutionary state, and I say this; we shall not relinquish! Maybe if they (CUF) overthrow us. A revolutionary government is not defeated in the ballot. This I tell you openly, they (CUF) don't have that power, because we $(\mathrm{CCM})$ are the ones with power'. 
During the campaigns, CCM senior leaders such as Balozi Iddi, Vuai Ali Vuai, Amina Salum Ali, Juma Borafya and Hamza spoke out openly against Maridhiano and the GNU. They felt that power-sharing had failed and the best way forward was a return to the winner-takes-all-system. The election competition between CCM and CUF had undermined the spirit of reconciliation and increased tensions, making co-operation in the next administration more difficult. Typical statements from CCM leaders during the campaigns included comments like those of Amina Salum Ali, speaking at a CCM rally at Kwa Mtipura on 6 October 2015 and observed by researchers: 'You can see CCM has a presidential flag, CUF doesn't have. Look at our flag. CUF cannot be allowed to win'.

In the final week of campaigning, a heavy military presence around key areas of Zanzibar such as the port, airport, television station (TV Zanzibar) and important roads was observed. The finalisation of the election campaigns showed a major rift between CCM and CUF, unlike the 2010 campaign which had been more reconciliatory.

\section{AN ELECTION ANNULLED}

On 25 October 2015 both Zanzibar and mainland Tanzania went to the polls, the fifth general elections since the reintroduction of multi-party politics in 1992. While the ZEC is the electoral management body in Zanzibar, the National Election Commission (NEC) is in charge of the elections in mainland Tanzania. ZEC oversees the presidential, House of Representative and councillor elections in Zanzibar, as well as administering the Union presidential and parliamentary elections on behalf of and under the oversight of NEC. Despite five years of a Government of National Unity in Zanzibar, the two governing parties, CCM and CUF, saw the 2015 elections as a must-win election, given the high stakes inserted into the Tanzanian constitutional review process and Zanzibar's status under the United Republic of Tanzania. National and international observer groups called it the best-run election ever on the isles, where the voting and counting process was generally peaceful and conducted according to the law. This was according to a joint statement on 29 October 2015 by the Commonwealth Observer Group, African Union, SADC and the EU, in which they expressed concern about the situation in Zanzibar. However, when it became clear during the tabulation and announcement of votes that CUF had won several constituencies previously held by CCM in Unguja, the Chairman of the Zanzibar Election Commission delayed further announcement. After some time, in a pre-emptive and what was considered a strategic political move, CUF's presidential candidate Maalim Seif Sharif Hamad called a press conference on 26 October 2015. He stated that 
according to an independent tally he had won the election and called upon ZEC to declare him the winner (The Guardian 2015). Part of the statement read:

As of 9.30 this morning, Maalim Seif Hamad, the presidential candidate of the Civic United Front in Zanzibar, had secured 200,077 votes against his rival Dr. Ali Mohamed Shein of CCM with 178,363 votes. This constitutes a majority for CUF of 21,714 votes $-52.87 \%$ against $47.13 \%$. The people of Zanzibar have spoken... [ ] There is now no question that Maalim Seif has won the presidential election in Zanzibar and that the ruling party has been defeated for the first time since 1977.

TEMCO 2015

CUF's announcement was quickly followed up by CCM who described it as a unilateral declaration which could create tensions and was illegal according to the Zanzibar Elections Act (The Citizen 2015). After two days of chaos, on 28 October ZEC Chairman Jecha Salim Jecha unilaterally annulled the elections after 31 of 54 constituencies had been tallied and their results announced, citing 'serious irregularities and gross violations of laws and election regulations' (The Guardian 2015). The Chairman also cited nine factors which had influenced his decision; these included the fighting among ZEC Commissioners and voting irregularities on Pemba island where many polling stations outnumbered the voters in the poll book (Daily News 2015). While NEC also oversees the elections of Union MPs in Zanzibar, it did not record any of the irregularities which were alleged by ZEC. It is important to note that the elections in both mainland Tanzania and Zanzibar run concurrently.

A day after the nullification of the election, the European Union Election Observer Mission together with the African Union, the Southern African Development Community (SADC) and the Commonwealth Observer missions issued a joint statement expressing their concern about this decision. According to the statement, the general conduct of the elections prior to the counting and verification process was in accordance with the election laws in Tanzania and they therefore called for a full disclosure of the nullification decision.

The nullification of the elections created a raft of legal and constitutional ramifications and plunged the isles into a political imbroglio. The decision to annul the elections was condemned by both international and domestic observer missions, most vehemently by the US Embassy in Tanzania which expressed 'grave concern' over the actions of the ZEC Chairman (TEMCO 2015). In a quick rebuttal, two ZEC Commissioners from CUF said the Chairman took this action alone and without informing or consulting with the other Commissioners, 
according to an interview with ZEC Commissioner Ayoub on 29 October 2015 in Stone Town, Zanzibar. They contended that the decision was illegal as it did not adhere to procedures outlined in the Zanzibar Elections Act. Section 3(2) of the Elections Act requires the Commission as a collective body to provide consent for any direction, instructions or announcements in regard to elections in Zanzibar. Pursuant to this, the Zanzibar Constitution (1984/2010) Section 119(10) outlines the quorum of the Commission in the following way: 'The quorum of the Commission is the Chairman or Vice Chairman and four members and every decision of the Commission shall be supported by the majority of the members of the Commission'.

The CUF declared that the results were contested and rejected by CCM, accusing CUF of manipulating the election process. They hence supported the decision by the ZEC Chairman to annul the election and move towards a reelection.

\section{INTER-PARTY NEGOTIATIONS AND THE RE-ELECTION}

With the elections annulled, inter-party negotiations between CCM and CUF began with an attempt to amicably resolve the burgeoning political stand-off in Zanzibar. The main issues discussed included the legality of nullifying the elections, a possible re-election, and the legitimacy of the government that was still being led by Ali Mohammed Shein. The talks involved the two protagonists, CCM presidential candidate Ali Mohamed Shein and Maalim Seif Shariff Hamad, the CUF presidential candidate, together with a host of CCM luminaries such as former Union President Ali Hassan Mwinyi and former Zanzibar Presidents Salmin Amour and Amani Abeid Karume, together with Second Vice President Seif Ali Iddi.

Regarding the legality of ZEC Chairman's act, CUF contended that the nullification was unconstitutional and contrary to the Election Law based on section 119 (10) of the Constitution which requires that every decision of the Commission be decided by the majority. In their argument CUF reiterated that the ZEC Chairman made the decision to annul the election without consulting the Commission and without getting majority approval. CUF also pointed out that the Chairman made the decision contrary to the election law, which makes it clear that results for the election of the Members of the House of Representatives and councillors, once verified and announced by the returning officers, may not be challenged except through an election petition. On their part, CCM stood by the ZEC Chairman arguing that the Chairman had made the decision not as an individual but as the Chairman of ZEC.

On the question of a possible re-election, CCM came to the meetings with 
only two options: re-election, failing which CUF would seek legal redress at the courts. CUF on the other hand was of the opinion that the re-election could not be called without first ascertaining the legality of the nullification. Maalim Seif proposed the formation of an independent, binding, arbitral tribunal composed of chief justices of East African countries such as Malawi, Kenya and Uganda. He also proposed that the two parties should provide terms of references to the tribunal and the two parties should make a prior undertaking agreeing to accept the findings of the tribunal. CCM refused this proposal, citing constitutional limitations as their reason without further elaboration. On the other hand, CUF's Maalim Seif rejected the proposal to take the matter to court. He cited three main grounds for this:

- the politicisation of the registrar of the courts in Zanzibar

- the lack of independence of high court judges; and

- the government treatment of the vice chairman of ZEC.

The deputy chair was a high court judge who had been arrested by the police while on election duty, probably to prevent him from announcing the results before the election was nullified. CUF took this as a clear indication that the government had no intention to respect the independence of the judiciary.

Furthermore, the issue of government legitimacy in the aftermath of the annulled election was extensively discussed. CUF was of the opinion that the presidential tenure had expired in accordance with the provisions of section 28(2) of the Zanzibar Constitution, although it was understood that the president was invoking the provisions of section 28(1) (a) which provides that the president will hold office until the next president is sworn in. But CUF asserted that the provision could not be used where the incumbent is part of the conspiracy, as he should not benefit from his own wrongdoing. CCM did not accept the points raised by the CUF in this regard. When the Attorney General was called to clarify the two issues, he addressed the first issue on presidential tenure as a purely literal interpretation of the Constitution, without addressing the meaning and application of section 28(2) and 29 which limit the presidential term and provide grounds for its extension.

Despite nine rounds of talks in late 2015 and early 2016 no agreement was reached, and ZEC Chairman announced in January 2016 that a re-election would be held on 20 March 2016. The announcement through state-run Zanzibar Broadcasting Corporation ( $\mathrm{ZBC})$, noted that the re-election would involve the president of Zanzibar, members of the House of Representatives and councillors; it would not be preceded by party nominations; and all candidates would remain on the ballot. Following this announcement, the CUF stated that they would 
boycott the re-election. CUF also tried to have all their candidates - presidential, House of Representatives and councillors - removed from the ballot. However, this was rejected by ZEC Chairman who said that the proper procedures were not followed and that this was probably a strategy to strengthen the 'legitimacy' of the re-elections and the CCM position.

On 20 March 2016 the re-election was conducted in Zanzibar with an unprecedentedly low turnout, as the main opposition party CUF and eight other political parties boycotted the re-election. The CUF stand was that their presidential candidate Seif Shariff Hamad had won the October election, those polls were free, fair, and credible, and there was no legitimate justification for either the annulment or the re-election process. ZEC announced Ali Mohammed Shein of CCM as winner with $91.4 \%$ of the votes; in additional, CCM won all the House of Representatives seats. With these results legal questions regarding the formation of a GNU were bound to arise.

According to Section 9(3) of the Zanzibar Constitution 2010 (translated by the authors) the structure of the Revolutionary Government of Zanzibar will be one of National Unity and its functions shall be to carry out its duties to enhance national unity and to attain democracy. To fulfill this provision, Section 39(1) of the Constitution provides for a first vice president and second vice president who shall according to Section 39(5) and 39(7) be principal advisors to the president. According to Section 39(3)(i) the first vice president shall come from the party that came second in the election and must have garnered not less than $10 \%$ of the vote. In the results detailed above, no party other than CCM garnered more than $10 \%$ share of the vote. Section 39(3)(i) and (ii) states that if an appointment does not occur, that is if no opposition party wins the requisite votes or when the president lacks a competitor, the seat goes to the party with the second largest number of seats in the House of Representatives. As such the seat of the first vice president shall remain vacant given that no second party met either of the thresholds for appointing a candidate for the position. Further, in Section 39A (3), the seat of the first vice president can remain vacant if, seven days after the president is sworn in, the party that came second fails to offer a name to the president. This notwithstanding, Ali Mohammed Shein went on to reappoint Balozi Seif Iddi as the second vice president on 28 March $2016 .{ }^{6}$

Regarding the formation of a cabinet, the Constitution states in Section 42(2) that the president in consultation with both his vice-presidents shall appoint cabinet ministers from the members of the House of Representatives, taking into consideration a portfolio balance of the parties represented in the House of

6 Balozi Seif Ali Iddi had served in the position of second vice president during the first GNU and is a known party hardliner in Zanzibar. 
Representatives. As all elected member were from the CCM, the unity government was de facto abolished. President Shein effectively ended the GNU when he announced a loyalist cabinet, albeit including three presidential candidates from minor loyalist opposition parties. CUF stated that they did not recognise Dr. Mohammed Shein's presidency or government as legitimate and announced a strategy of civil disobedience. Therefore, the culmination of the re-election in Zanzibar marked the end of the Maridhiano spirit in Zanzibar.

\section{CONCLUSION}

Mehler has argued that power-sharing remains in vogue, and through an examination of power-sharing agreements in Liberia, Cote d'Ivoire and Kenya he contends that power-sharing agreements do not necessarily offer miraculous solutions to complex crises (Mehler 2009). Ian Spears argues that power-sharing agreements temporarily offer transitional remedies and not long-term conflict resolutions (Spears 2002). Aley Nassor and Jim Jose, in their analysis of Zanzibar, argued that Zanzibar's experiment in power-sharing demonstrates that a multi-party political system need not be structured according to a two-party oppositional model so as to achieve sustainable democratic consolidation (Nassor \& Jose 2014).

This article demonstrates the challenges of sustaining a power-sharing agreement in the form of a GNU in Zanzibar. Drawing from the literature around consensus democracy, we argue that intervening variables such as the constitutional review process and the election contributed to the re-emergence of enemy images in Zanzibar. This in turn led to the end of the Maridhiano spirit after a five-year experiment. The rift between CCM and CUF widened, leading to increasingly harsh political rhetoric against each other and withering the spirit of co-operation and partnership within the GNU as well as in the populace at large (Roop, Tronvoll \& Minde 2018). The controversial re-election in March 2016 proved to be the end of the Mariadhiano spirit and the end of the first-phase GNU. The GNU format is still constitutionally enshrined, however, and pending electoral participation and outcome 2020, it may re-emerge from the ashes.

\section{Acknowledgment}

This article was written as part of a project on Zanzibar's political history supported by the Royal Norwegian Embassy in Dar es Salaam. The authors of this article are solely responsible for its contents. The Embassy does not assume any responsibility for any omissions, errors or inaccuracies that may occur in this article. Nor does the Embassy necessarily concur with the analysis, assessment or opinions expressed in this article. 


\section{- REFERENCES}

Anglin, DG 2000, 'Zanzibar: Political Impasse and Commonwealth Mediation', Journal of Contemporary African Studies vol.18, no.1, pp. 39-66.

Bakari, A 2014, https://www.youtube.com/watch?v=nQW3VP1W5hU

Bakari, M \& Makulilo, A 2012, 'Beyond Polarity in Zanzibar? The 'Silent' referendum and the Government of National Unity', Journal of Contemporary African Studies, vol.30, no.2, pp. 195-218.

Boswell, R 2008, 'Scents of identity: Fragrance as heritage in Zanzibar', Journal of Contemporary African Studies vol. 26, no. 3, pp. 295-311.

Cameron, G 2002, 'Zanzibar's Turbulent Transition', Review of African Political Economy vol. 29, no.92, pp. 313-330.

Cheeseman, N 2011, 'The internal dynamics of power-sharing in Africa', Democratization vol. 18, no. 2, pp. 336-365.

Cheeseman, N \& Tendi, BM 2010, 'Power-sharing in comparative perspective: the dynamics of 'unity government' in Kenya and Zimbabwe', Journal of Modern African Studies vol. 48, no. 2, pp. 203-229.

Civic United Front Tanzania Manifesto 2015-2020, <http://www.temco.udsm.ac.tz/ images/stories/Election_Manifesto/ILANI_CUF_2015.pdf>

Daily News, 2015, 'Zanzibar election results nullified', Accessed 15 January 2015, Available at <http://www.dailynews.co.tz/index.php/2015-elections/43688zanzibar-election-results-nullified>

Fouéré, MA 2014, 'Recasting Julius Nyerere in Zanzibar: the Revolution, the Union and the Enemy of the Nation', Journal of Eastern African Studies vol. 8, no. 3, pp. 478-496.

Glassman, J 2011, War of Words, War of Stones: Racial Thought and Violence in Colonial Zanzibar, Indiana University Press, Indiana.

Hamid, Mansoor 2015, Speech, Available at: <https://www.youtube.com/ watch?v=W8z52DMqO1k $>$, [Accessed 23.2.15]

Heads of Election Observer Mission in Tanzania, 2015, 29 October.

http://thecommonwealth.org/media/news/international-observers-expressconcern-situation-zanzibar

Hutton, L 2015, 'The Tanzanian election 2015: Balancing stability and change'. Available at: <https://issafrica.s3.amazonaws.com/site/uploads/East_Africa_ Report6.pdf $>$, [Accessed 12 November 2017].

Karume, S 2004, 'Political conflicts in Zanzibar: A social, economic and political interpretation', in S Karume (ed), Dilemmas of Political Transition: Towards Institutionalisation of Multiparty Democracy in Tanzania, EISA, Johannesburg, pp. 7-33. 
Killian, B 2008, 'The State and Identity Politics in Zanzibar: Challenges to Democratic Consolidation in Tanzania', African Identies vol. 6, no. 2, pp. 99-125.

Mehler, A 2009, 'Peace and Power Sharing in Africa: A not so Obvious Relationship', African Affairs vol. 108, no. 432, pp. 453-473.

Mmuya, M 2003, Managing Stand-off Politics in Tanzania: The Case of Chama Cha Mapidunzi (CCM) and the Civic United Front (CUF), Institute of Development Policy and Development Research, Bochum.

Moss, SM. \& Tronvoll, K 2015 "'We are all Zanzibari!" Identity formation and political reconciliation in Zanzibar', Journal of Eastern African Studies vol. 9, no. 1, pp. 91-109.

Mukherjee, B 2006, 'Why Political Power-Sharing Agreements Lead to Enduring Peaceful Resolution of Some Civil Wars, But Not Others?', International Studies Quarterly vol. 50, no. 2, pp. 479-504.

Nassor , AS. \& Jose, J 2014, 'Power-Sharing in Zanzibar: From Zero- Sum Politics to Democratic Consensus?', Journal of Southern African Studies vol. 40, no. 2, pp. 247-265.

Roop, S, Tronvoll, K \& Minde, N 2018, 'The politics of continuity and collusion in Zanzibar: political reconciliation and the establishment of the Government of National Unity', Journal of Modern African Studies vol. 56, no. 2, pp. 245-267. Sadallah, M 2015, 'CCM Zanzibar throw out Veteran'. [Online] Available at: http://www.thecitizen.co.tz/News/national/CCM-Z-bar-throwout-veteran/-/1840392/2691350/-/e35ysa/-/index.html>[Accessed 11 January 2016].

Spears, IS 2002, 'Africa: The Limits of Power-Sharing', Journal of Democracy vol. 13, no. 2, pp. 123-136.

TEMCO Tanzania Election and Monitoring Committee, 2015 Report of the Commonwealth Observer Group Tanzania General Elections 25 October 2015. Available at: <http://thecommonwealth.org/sites/default/files/ inline/2015\%20Tanzania\%20COG\%20FINAL\%20REPORT_PRINT.PDF> [Accessed November 2016].

TEMCO 2015, Interim Statement on Tanzania 2015 General Election, University of Dar es Salaam, Dar es Salaam. Available at: <http://www.temco.udsm.ac.tz/ images/stories/Interim_Statements/TEMCO_INTERIM_STATEMENT_ON_ TANZANIA_2015_GENERAL_ELECTIONS-ENG-VER.pdf>

The Citizen, 2015, 'Tense situation in Zanzibar as CUF and ruling party battle for control', Available at: <http://www.thecitizen.co.tz/tanzaniadecides/Zanzibar-insecurity-lockdown-as-parties-eye-victory/-/2926962/2931670/-/lr5961/-/index. $\mathrm{html}>$ [Accessed 14 January 2016].

The Commonwealth Observer Group 2015, <http://thecommonwealth.org/media/ news/international-observers-express-concern-situation-zanzibar> 
The Commonwealth Observer Group 2015, Tanzania General Elections 2015: Observer Group Interim Statement. Available at: <http://thecommonwealth.org/media/ news/tanzania-general-elections-2015-observer-group-interim-statement> [Accessed November 2016].

The Guardian 2015, 'Mixed reactions to ZEC move on Zanzibar polls US urges electoral commission to rescind annulment order'. Available at: $<$ http://www. ippmedia.com/?1=85670> [Accessed 15 January 2016].

The Guardian 2015, 'Police teargas CUF supporters as Hamad declares victory'. Available at: $<$ http://www.ippmedia.com/?l=85610 > [Accessed 14 January 2016].

Tronvoll, K 2006, ‘Bridging Divided Identities - or an Agency of Political Domination? Reassessing the Future of the Tanzanian Union', International Journal of Minority and Group Rights, Vol. 13, pp. 223-241.

Zanzibar 1984 (2010), Constitution, Zanzibar.

Zanzibar 2010, Katiba ya Zanzibar ya 1984, Toleo la 2010, Mpiga chapa wa Serikali ya Zanzibar, Zanzibar.

Zanzibar 2015, State House press release issued on 27 September 2015. Available at: $<$ http://www.ikuluzanzibar.go.tz/highlights/view/hoja-inayotolewa-na-cufya-kutaka-kuleta-mamlaka-kamili-ni-dhamira-ya-kumre> 